\title{
Wybrane metody rehabilitacji dziecka z zaburzeniami słuchu i mowy
}

\section{KEY WORDS}

child, hearing defect, rehabilitation, music, movement

\begin{abstract}
Konarczak-Stachowiak Agnieszka, Wybrane metody rehabilitacji dziecka z zaburzeniami słuchu i mowy [Some Methods of the Rehabilitation of a Child with Hearing and Speaking Disorders]. Kultura - Społeczeństwo - Edukacja nr 2(10) 2016, Poznań 2016, pp. 305-313, Adam Mickiewicz University Press. ISSN 2300-0422. DOI 10.14746/ kse.2016.10.23.
\end{abstract}

Music therapy and choreotherapy are two extensive term. They do not apply only music, movement and therapy, but they include a lot of modern science, for example: psychology, music psychology, psychotherapy, psychiatry, medicine, pedagogy, special pedagogy, music education, physic education, audiology, acoustics, psychoacoustic, speech therapy, sociology, music philosophy, musicology and diffrent kind of therapy by art and movement. Therefore sound therapy and movement therapy is trans-disciplinary. It is unique thing like music and natural thing like movement.

Basic kind of movement with music in therapy and rehabilitation: dance, recreation with music and movement, gymnastic with music and physical improvisation. The effectiveness of methods that use sound and movement in hearing and speech therapy is due to fact that: music and speech include rhythm, melody, tempo, volume, articulation, timbre, phrasing, accents etc.; speech development can coincide with motor development. The movement is main form child's development. Disorders in the motor development of the child have a direct or indirect impact on the development of the child's speech. When we teach our child motor development, also we support the development of speech, becouse the brain has one point that connect these two features.

Music and movement activities with elements of music therapy, choreotherapy and rhythm therapy trains sense of rhythm, hearing and music memory and it is very important for harmonious and quiet growing up child's - on a intellectual, physical, emotional and social plane, because of it all of processes that work in adult organism are improved. Main objective of the activities is develop different skills, attitudes and habits. 
Prawidłowo funkcjonujący narząd słuchu jest dla dziecka jedną z ważniejszych dróg poznawania świata, warunkiem rozwoju mowy dźwiękowej i komunikacji językowej. Wszelkie niedobory w odbiorze dźwięków występujące u dziecka w okresie kształtowania się mowy i języka powodują opóźnienia tego procesu, często zupełnie go zaburzając. Ma to swoje reperkusje we wszystkich sferach życia, a w szczególności w zakresie edukacji i zachowań społecznych. Wczesne rozpoznanie problemów z prawidłowym słyszeniem ma ogromne znaczenie dla skuteczności terapii. Liczy się czujność i aktywność wszystkich środowisk, w których przebywa dziecko - przedszkola, szkoły oraz domu. Zatem rodzice, opiekunowie dzieci oraz nauczyciele powinni mieć przynajmniej podstawową wiedzę o objawach sugerujących zaburzenia słuchu (Uczeń - zmysły, komunikacja..., 2004).

Badania prowadzone przez Instytut Fizjologii i Patologii Słuchu wykazały, że w Polsce zaburzenia słuchu występują u 4-6 noworodków na 1000, 2-4\% przedszkolaków i aż około $20 \%$ uczniów szkół podstawowych, gimnazjów i szkół średnich. Najczęstszą przyczyną niedosłuchu u dzieci (w 70\%) są zmiany zapalne i ich powikłania - możliwe do skutecznego leczenia w przypadkach wczesnego wykrycia. Służą temu badania przesiewowe prowadzone w placówkach medycznych i oświatowych. Również trwały niedosłuch odbiorczy można skutecznie leczyć poprzez rehabilitację za pomocą aparatów słuchowych lub implantów ślimakowych. Nowoczesne leczenie i postęp techniczny sprawiają, że coraz więcej dzieci korzystających $\mathrm{z}$ tych urządzeń uczy się w szkołach powszechnych i korzysta $z$ edukacji $w$ ramach integracji ze słyszącymi rówieśnikami. Jest to jednak trudne wyzwanie, zarówno dla dzieci, ich rodzin oraz pedagogów i terapeutów.

Nieleczony niedosłuch może powodować szereg negatywnych konsekwencji w zakresie rozwoju drogi słuchowej, mowy, języka, umiejętności czytania i pisania, a także komunikacji i funkcjonowania społecznego.

Aktywne słuchanie i mówienie są sprawnościami i trzeba się ich uczyć, tak jak wszelkich innych umiejętności. Mowa dziecka niesłyszącego rozwija się analogicznie jak mowa dziecka słyszącego, tylko z powodu uszkodzenia słuchu odbywa się to wolniej, z opóźnieniem, z dużymi trudnościami i wymaga szczególnej pomocy pedagogicznej i logopedycznej. Celem terapii logopedycznej powinno być doprowadzenie do takiego stanu, aby wszystkie działania wokół mowy dziecka odbywały się $\mathrm{w}$ prawidłowym kontakcie emocjonalnym i w różnych sytuacjach zabawowych oraz przy wykorzystaniu wszystkich zmysłów. W przypadku dzieci $\mathrm{z}$ wadą słuchu surdologopeda zajmuje się nie tylko i nie wyłącznie korygowaniem wad wymowy, lecz kształci, rozwija i usprawnia umiejętności językowe dziecka od podstaw, uczy dziecko komunikowania się z otoczeniem. W tych zadaniach powinien być wspierany przez świadomych swej roli nauczycieli przedszkoli i nauczania początkowego. 
Dzieci, wstępując do szkoły, wykazują dość szeroką rozpiętość w zakresie przygotowania do podjęcia obowiązku szkolnego - zarówno pod względem motorycznym, intelektualnym, emocjonalnym, społecznym, jak i pod względem mowy. Uzyskany jednak przez dziecko stopień rozwoju mowy i języka jest jednym $\mathrm{z}$ ważniejszych kryteriów oceny dojrzałości szkolnej. Jeśli dziecko zaczęło mówić z poważnym opóźnieniem, to nie można oczekiwać, że rozwój jego mowy w wieku 6-7 lat będzie zgodny ze standardem. Obowiązek szkolny podejmują również dzieci, u których w okresie przedszkola nie zlikwidowano wad wymowy, bądź to przez zaniechanie, bądź przez poważny charakter wady. Obowiązek szkolny podejmują także dzieci z poważną wadą słuchu, które prezentują duże zaległości w rozwoju języka w płaszczyznach: dźwięków, słownictwa i gramatyki. Okres adaptacji szkolnej oraz intensywna nauka, jaka ma miejsce w pierwszej klasie, nie sprzyjają wyrównywaniu tych zaległości. Szczególne trudności w sprostaniu wymaganiom szkolnym mają dzieci $\mathrm{z}$ wadą słuchu. Mają one trudności $\mathrm{w}$ realizacji programu szkolnego, skupieniu uwagi, podążaniu za wymaganiami nauczyciela, panowaniu nad swoimi reakcjami emocjonalnymi, odnalezieniu się w grupie rówieśniczej, często występuje regres w rozwoju ich mowy spowodowany intensywną nauką czytania i pisania. U progu nauki szkolnej dziecko słyszące powinno mieć bogate umiejętności komunikowania się językowego - pełną sprawność wymawiania wszystkich głosek języka polskiego, znaczną sprawność systemową, a więc posługiwanie się poprawnym, gramatycznym zdaniem, także złożonym. Wszelkie zaburzenia słyszenia występujące w tym okresie lub we wcześniejszych latach życia dziecka wywołują natychmiastowe skutki poprzez ograniczenie uwagi i możliwości poznawczych. $Z$ badań prowadzonych przez Instytut Fizjologii i Patologii Słuchu wynika, że problem ze słuchem powstaje często nagle lub stopniowo w okresie przedszkolnym i szkolnym i długo pozostaje niezauważony przez opiekunów (Uczeń - zmysty, komunikacja..., 2004). Wpływa na zachowanie dziecka, jego koncentrację, pogorszenie zdolności poznawczych, a często wręcz zahamowanie rozwoju.

Typowe objawy sugerujące możliwość występowania zaburzeń słuchu to:

- opóźnienie rozwoju mowy lub ograniczony zasób języka,

- niewyraźna mowa, gubienie początków lub końcówek wyrazów,

- problemy z pisaniem ze słuchu (dziecko pisze tak jak słyszy),

- obserwowanie twarzy osoby mówiącej,

- rozkojarzenie, problem z koncentracją uwagi, rozglądanie się po klasie w czasie, gdy inni wykonują polecenie nauczyciela,

- zdziwienie, gdy dziecko uświadamia sobie, że jest wywoływane po imieniu,

- opóźnione reagowanie lub brak odpowiedzi na zawołanie,

- utrudnienia w rozumieniu poleceń w hałasie, np. na przerwie, 
- częste prośby o powtórzenie, dopytywanie się „co”, częste trudności ze zrozumieniem pytania,

- częste nieprzygotowanie do lekcji z powodu nierejstrowania przez dziecko tematu pracy domowej,

- siadanie blisko telewizora, zwiększanie głośności,

- siadanie blisko nauczyciela lub zajmowanie się samym sobą w końcu sali,

- trudności z lokalizacją dźwięku,

- głośne mówienie,

- gorsze wyniki w nauce,

- siedzenie w klasie w czasie przerwy,

- uciekanie przed hałasem,

- bóle głowy mogące być objawem nadwrażliwości na dźwięki,

- słyszenie dźwięków, których inni nie słyszą (piski, szumy, gwizdy, dzwonienie),

- niesłyszenie dzwonka oznajmiającego przerwę,

- dysleksja, dysgrafia,

- zawroty głowy, zaburzenia równowagi.

Zasady logopedycznej pracy z dzieckiem z wadą słuchu zachowują związek z podstawowymi regułami obowiązującymi w logopedii i surdopedagogice, które z kolei podlegają ogólnym normom dydaktycznym - systematyczność, stopniowanie trudności, utrwalanie, indywidualizację oraz aktywny i świadomy udział dziecka. W surdologii jedną z podstawowych zasad jest całościowe spojrzenie na dziecko. Badania naukowe podkreślają, że dziecko niesłyszące należy traktować jako integralną jednostkę o specjalnych potrzebach edukacyjnych. Wada słuchu, choć stwarza poważne przeszkody w kształtowaniu się mowy, porozumiewaniu się słowem oraz w ogólnym rozwoju, nie wyklucza możliwości uzyskania takich samych umiejętności i wiadomości, jakie osiągają osoby słyszące (Gunia 2010: 130).

$\mathrm{W}$ pracy $\mathrm{z}$ dzieckiem $\mathrm{z}$ wadą słuchu obowiązują zasady dobrowolności, atrakcyjnoiści, krótkotrwałych ćwiczeń, prowadzenia zajęć w formie zabaw i gier oraz zasada tworzenia sprzyjającej atmosfery. Dobór metod w praktyce logopedycznej zależy od wielu zmiennych, takich jak: wiek dziecka, istota zaburzenia, rodzaj i stopień niedosłuchu, rodzaj urządzeń wspomagających słyszenie, cele, zadania oraz środki i organizacja procesu terapeutycznego. Podział metod w opracowaniu K. Błachnio obejmuje:

a) metody werbalne:

- lingwistyczne,

- filologiczne,

- psychologiczne,

- pedagogiczne; 
b) metody pozawerbalne:

- rysunkowe,

- taneczno-muzyczne,

- motoryczno-kinestetyczne,

- wzrokowo-słuchowo-dotykowe,

- wzrokowo-słuchowo-ruchowe. (Gunia, 2010: 140)

Metoda lingwistyczna uwzględnia cztery podstawowe elementy składowe mowy:

a) rozumienie, czyli odbiór wypowiedzi słownej, sygnalizacyjnej i graficznej, który realizujemy przez wykorzystywanie i rozwijanie resztek słuchowych oraz odczytywanie wypowiedzi z ust;

b) mówienie, czyli budowanie treści pojęciowych związanych z myśleniem i pracą narządów mownych;

c) budowanie tekstu, czyli wypowiedzi poprawnych pod względem formy językowej i substancji w płaszczyznach suprasegmentalnej (akcent, tempo, rytm, melodia) i segmentalnej (głoski);

d) kształcenie języka za pomocą wzrokowo-słuchowej techniki pracy - obserwacji procesu artykulacyjnego, przy wykorzystaniu i rozwijaniu resztek słuchowych oraz kształceniu techniki odczytywania wypowiedzi z ust.

Rozumienie materiału językowego odbieranego przez dziecko $\mathrm{z}$ wadą słuchu jest łatwiejsze, jeśli słowo mówione jest wspomagane etykietą, poparte konkretną sytuacją lub doświadczeniem dziecka.

Metoda filologiczna ściśle łączy się z materiałem literackim, takim jak opowiadanie, nowela, tekst, wiersz, piosenka, zagadka. Wykorzystywanie literatury w pracy surdologopedycznej ma na celu budzenie zainteresowania tekstem, rozwijania umiejętności słuchania i rozumienia treści.

Metoda psychologiczna ma za zadanie oddziaływanie terapeuty na psychikę dziecka w celu kształtowania zaufania do działań logopedycznych, zwiększenia wiary we własne siły, podniesienia samooceny i zmiany emocjonalnego stosunku do wady i wynikających z niej zaburzeń oraz obniżenia ogólnego napięcia emocjonalnego.

Metoda pedagogiczna to ścisłe powiązanie działań logoterapeutycznych z systemem nauczania. Wykorzystanie w terapii szeregu technik dydaktycznych. Podporządkowanie działań rehabilitacyjnych prawidłowościom postępowania dydaktycznego, które wyznacza cele, treści, zasady, formy i środki dydaktyczne.

Metoda rysunkowa pomaga wyrazić dziecku swoje myśli, spostrzeżenia, emocje, wrażenia i wyobrażenia $w$ formie graficznej, dlatego w praktyce logopedycznej często stosuje się rysunek jako materiał do określonych ćwiczeń, jako formę twórczej aktywności dziecka oraz jako materiał do diagnozy. 
Metoda taneczno-muzyczna to różnorodne ćwiczenia ruchowe przy muzyce, które wykorzystuje się w profilaktyce oraz kompensacji, usprawnianiu i kształtowaniu prawidłowego psychomotorycznego dziecka. Funkcja kompensacyjna opiera się na związku ruchu $\mathrm{z}$ muzyką, który wykorzystujemy w wychowaniu słuchowym do kształtowania wrażliwości czuciowo-ruchowo-słuchowej.

Metoda motoryczno-kinestetyczna ma na celu kształtowanie u dziecka umiejętności i nawyków artykulacyjnych. Ściśle wiąże się z ogólnym usprawnianiem ruchowym dziecka, ze szczególnym zwróceniem uwagi na motorykę oralną.

Metoda wzrokowo-słuchowo-dotykowa - w zakresie wzrokowej percepcji mowy stosuje się odczytywanie wypowiedzi z ust, natomiast w wypadku zmysłu dotyku wibracje odbierane opuszkami palców wykorzystuje się do odróżniania głosek, na przykład dźwięcznych od bezdźwięcznych, ustnych od nosowych (wyczuwając dłonią drgania więzadeł głosowych lub drgania skrzydełek nosa).

Metody terapii logopedycznej dziecka $\mathrm{z}$ wadą słuchu należy zawsze dobierać do indywidualnych możliwości dziecka oraz do warunków środowiska, w którym się ono rozwija.

Proces terapeutyczny dziecka $\mathrm{z}$ wadą słuchu obejmuje ćwiczenia przede wszystkim słuchowe, ale oczywiście także oddechowe, usprawniające motorykę narządów artykulacyjnych, fonacyjne, artykulacyjne, w odczytywaniu wypowiedzi z ust, logorytmiczne, kształtujące stronę leksykalną i gramatyczną, a także ćwiczenia stymulujące percepcję wzrokową, ruchową i dotykową, ćwiczenia w czytaniu i pisaniu, ćwiczenia korekcyjno-wyrównawcze.

Dzieci z wadą słuchu mają potencjalną potrzebę i zdolność odbierania, tworzenia i wyrażania muzyki oraz są wrażliwe na bodźce muzyczne przychodzące dostępnymi im kana-

łami. (Jarkowska, 2004)

Muzykoterapia i choreoterapia to dyscypliny bardzo szerokie. Nie ograniczają się one w swojej istocie tylko do muzyki, ruchu i terapii, ale odnoszą się do wielu dziedzin współczesnej wiedzy - psychologii ogólnej, psychologii muzyki, psychoterapii, psychiatrii, medycyny, pedagogiki ogólnej, pedagogiki specjalnej, edukacji muzycznej, edukacji fizycznej, audiologii, akustyki, psychoakustyki, logopedii, socjologii i filozofii muzyki, muzykologii oraz różnych form terapii przez sztukę i terapii przez ruch. Terapia dźwiękiem i ruchem jest więc transdyscyplinarna. I nie jest własnością jednej kultury, kraju, rasy czy płci. Jest czymś uniwersalnym, tak jak uniwersalna jest muzyka i tak jak czymś naturalnym jest ruch.

Proces terapeutyczny w muzykoterapii bazuje na relacji: pacjent - muzyka terapeuta.

Ze względu na techniki stosowane w terapii dźwiękiem zasadniczo wyróżnia się podział na muzykoterapię receptywną, której podstawą jest słuchanie muzyki, relaksacja, wizualizacja oraz muzykoterapię aktywną, w której fundamentem 
działania są różne formy aktywności muzycznej Pacjenta: śpiew, ruch z muzyką, gra na instrumentach, tworzenie i słuchanie muzyki.

Wykorzystanie ruchu w terapii to choreoterapia - proces który bazuje na relacji pacjent - ruch - terapeuta. Zaś proces terapeutyczny oparty o metody z elementami i muzykoterapii i choreoterapii bazuje na relacji: pacjent - muzyka ruch - terapeuta.

Muzyka i ruch $\mathrm{z}$ powodzeniem są stosowane w pracy nie tylko z pacjentami (dziećmi oraz dorosłymi) z uszkodzonym narządem słuchu, ale także $\mathrm{z}$ innymi osobami o specjalnych potrzebach edukacyjnych:

- $\mathrm{z}$ uszkodzonym narządem wzroku,

- $\mathrm{z}$ upośledzeniem umysłowym,

- z zaburzeniami komunikacji językowej,

- $\mathrm{z}$ uszkodzeniami motorycznymi,

- ze sprzężonymi niepełnosprawnościami,

- z zaburzeniami emocjonalnymi i zachowania,

- $z$ autyzmem i pokrewnymi zaburzeniami,

- ze specyficznymi trudnościami w uczeniu się,

- z przewlekłymi chorobami somatycznymi.

Ruch jest dominującą formą aktywności dziecka w jego rozwoju i stymulacji mowy. Podstawowe formy ruchu $\mathrm{z}$ muzyką wykorzystywane $\mathrm{w}$ terapii i rehabilitacji to: taniec, zabawa muzyczno-ruchowa, gimnastyka przy muzyce, opowieść ruchowa oraz ruchowa improwizacja.

Skuteczność metod wykorzystujących dźwięk i ruch w terapii surdologopedycznej - terapii słuchu i mowy - wynika między innymi z faktów, iż:

- muzyka i mowa składają się z tych samych elementów: rytm, melodia, tempo, natężenie, artykulacja, barwa, frazowanie, akcenty, pauzy itd.,

- rozwój mowy idzie, bądź nie, w parze z rozwojem ruchowym.

Zaburzenia w rozwoju ruchowym dziecka mają bezpośredni lub pośredni wpływ na rozwój mowy dziecka. Stymulując dziecko w celu jego prawidłowego rozwoju ruchowego, jednocześnie pośrednio wspieramy także rozwój jego mowy - między innymi dlatego, że za rozwój i ruchowy i mowy odpowiadają w mózgu te same ośrodki.

Zastosowanie $\mathrm{w}$ rehabilitacji dzieci z wadą słuchu znajduje także logorytmika - terapia słowem, muzyką i ruchem. Istotą tej metody jest ścisły związek ruchu z muzyką łączonych z rytmizowanym mówieniem i śpiewem oraz z charakterystycznym instrumentarium Carla Orffa. To właśnie rytmizacja tekstów oraz śpiew są głównymi formami w logorytmice kształtującymi aparat głosotwórczy, regulującymi oddech i usprawniającymi aparat artykulacyjny. Logorytmika w edukacji i terapii dziecka to: ćwiczenia i zabawy słowne, ruchowe, słuchowe, słuchowo-ruchowe oraz muzyczno-ruchowe. 
Kolejną metodą, posługującą się muzyką lub jej elementami oraz ruchem, jest rytmikoterapia, w sposób szczególnie skuteczny wykorzystywana $\mathrm{w}$ pracy z zaaparatowanymi i zaimplantowanymi seniorami. Rytmikoterapia to gimnastyka umysłu i ciała, forma terapii przez ruch przy muzyce, który stymuluje aktywność psychiczną oraz pełni rolę aktywizującą.

Twórca rytmiki - Emil Jaques-Dalcroze uważał, że aby pacjent odczuwał muzykę, nie wystarczy rozwijać w nim zdolności słuchowych - elementem najsilniej oddziałujacym na zmysty jest rytm.

W przypadku dzieci terapię opartą na rytmie warto już stosować przed implantacją. Rytmizacja $\mathrm{z}$ wielkim powodzeniem wspiera ich kompetencje prewerbalne.

Zajęcia muzyczno-ruchowe z elementami muzykoterapii, choreoterapii, logorytmiki oraz rytmikoterapii oprócz umuzykalniania, kształcenia poczucia rytmu oraz rozwijania słuchu i pamięci muzycznej, pełnią szczególną rolę we wszechstronnym, harmonijnym rozwoju dziecka - intelektualnym, fizycznym, emocjonalnym i społecznym oraz usprawniają wszystkie procesy zachodzące w organizmie dorosłego człowieka. Głównym celem tych zajęć jest kształtowanie różnych umiejętności, sprawności, postaw i nawyków.

Terapeutyczne zajęcia muzyczno-ruchowe, miedzy innymi:

- usprawniają procesy myślowe,

- usprawniają funkcje słuchowe - słuch fizyczny, fonematyczny i muzyczny,

- rozwijają percepcję słuchową i wzrokową,

- rozwijają koordynację słuchowo-wzrokowo-ruchową,

- usprawniają funkcje - oddechową, fonacyjną i artykulacyjną,

- kształcą pamięć i uwagę słuchową,

- doskonalą koncentrację,

- usprawniają małą i dużą motorykę,

- wspomagają rozwój mowy,

- uwrażliwiają na elementy wspólne dla muzyki i mowy - rytm, melodię, tempo, dynamikę, artykulację, akcenty, frazowanie, pauzy czy kolorystykę brzmieniową,

- rozwijają wyobraźnię, kreatywność i ekspresję,

- kształtują sprawności psychoruchowe,

- usprawniają ciało,

- wyrabiają spostrzegawczość,

- kształtują świadomość własnego ciała oraz gospodarowania przestrzenią wokół,

- uczą wyrażania emocji,

- rozwijają postawy twórcze,

- uczą pracy w zespole. 
Zajęcia muzyczno-ruchowe są adresowane zarówno do dzieci o prawidłowym przebiegu rozwoju, jak i do dzieci $\mathrm{z}$ deficytami - $\mathrm{w}$ tym $\mathrm{z}$ wadą słuchu, a także dla młodzieży i seniorów.

Muzykoterapia, choreoterapia, logorytmika oraz rytmikoterapia mogą być prowadzone między innymi w szpitalach, ośrodkach terapii, ośrodkach rehabilitacyjnych, sanatoriach, placówkach resocjalizacyjnych, placówkach edukacyjnych (między innymi w żłobkach, przedszkolach i szkołach), w ośrodkach wsparcia, a także w gabinetach prywatnych.

Kluczowym jest indywidualne, profesjonalne, kompetentne podejście terapeuty oraz współpraca wszystkich osób zaangażowanych w proces rehabilitacyjny Pacjenta, ukierunkowana na wspomaganie podczas wszystkich etapów zaplanowanych działań terapeutycznych.

\section{Literatura}

Baczała D., Błeszyński J. (red.). (2014). Muzyka w logopedii. Terapia, wspomaganie, wsparcie. Trzy drogi, jeden cel. Toruń.

Gąsienica-Szostak A. (2003). Muzykoterapia w rehabilitacji i praktyce. Warszawa.

Gunia G. (2010). Terapia logopedyczna dzieci z zaburzeniami słuchu i mowy. Wybrane problemy teorii i praktyki surdologopedycznej. Kraków.

Jarkowska A.E. (2004). Muzyka jako element wychowania. Tychy.

Uczeń - zmysły, komunikacja, Stowarzyszenie Przyjaciół Osób Niesłyszących i Niedosłyszących, Instytut Fizjologii i Patologii Słuchu, Warszawa 2004. 
